\title{
In vitro formation of adventitious shoots on caulinary tissue of physiologically contrasting Agave angustifolia plants
}

\author{
Suzel del Carmen Ríos-Ramírez¹, José Raymundo Enríquez-del Valle', Gerardo Rodríguez-Ortiz ${ }^{1 *}$, Judith \\ Ruíz-Luna ${ }^{2}$, Vicente Arturo Velasco-Velasco ${ }^{1}$ \\ 1División de Estudios de Posgrado e Investigación-Instituto Tecnológico del Valle de Oaxaca (ITVO), Nazareno, Xoxocotlán, Oaxaca, Zip Code \\ 71230, México, 2Faculty of Biology-Instituto Tecnológico del Valle de Oaxaca (ITVO), Nazareno, Xoxocotlán, Oaxaca, Zip Code 71230, México
}

\section{A B S TR A C T}

To micropropagate agave plants, somatic tissue is obtained from selected plants that are conditioned for 2 to 6 months to improve their physiological condition and health before in vitro cultivation. The objective of this study was to evaluate the physiological condition of Agave angustifolia plants in terms of its effect on organogenic response in somatic tissue taken from these plants when they are established in similar culture media. In a nursery, growth of four groups of plants was evaluated when they were subjected to different types of irrigation for seven months: 1) water; 2) NS-50\% (fertigation with nutrient solution at $50 \%$ strength); 3) NS-75\%; and 4) NS$100 \%$. At the end of the period, it was found that supplying nutrients is important for plants to achieve better physiological condition. The unfertilized plants and those that received NS-75\% had increases of 3.8 and 7.8 leaves, 6.5 and $12.5 \mathrm{~cm}$ in length of the largest leaf, and 1610.3 and $4401.4 \mathrm{~cm}^{2}$ in leaf area. Stem tissue was obtained from these stock plants and cultured for 90 days in in vitro culture, and formation of adventitious shoots was assessed. The results showed that the magnitude of organogenesis in stem tissue for formation of adventitious shoots was positively related to the physiological condition of the stock plant. Explants taken from unfertilized stock plants formed 14.6 total shoots and 3.8 shoots on each explant, while those fertigated at $100 \%$ concentration of nutrients formed 32.7 total shoots and 8 shoots on each explant.

Keywords: Adventitious shoots; Caulinary tissue; Nutrient solution (NS); Organogenesis

\section{INTRODUCTION}

In the state of Oaxaca, Mexico, several species of cultivated and wild agaves are used as raw material for produce a distillate beverage named mescal. During the period 2006 to 2013, Agave plantations covered 13,572 ha. Most were mature crops, and so around four thousand ha were harvested yearly (SAGARPA, 2013). Agave angustifolia Haw. is economically the most important species. It occupies $77.4 \%$ of the area under agave, and is established at a density of 2000 plants / ha (CONABIO, 2006; Aguirre and Eguiarte 2013). In 2014 Oaxaca produced 2.7 million liters of mescal and exported $96.1 \%$ of the total production (Nolasco, 2015), which had a total value of U.S. $\$ 8.9$ million.

Agave angustifolia has a production cycle that varies from seven to nine years (Antonio and Ramírez, 2008). It is necessary to propagate approximately 3.7 million plantlets yearly to replace harvested plants. Because of the intensity the areas were harvested during 2013 to 2015, the state's agave inventory decreased notably. The descriptions of Arizaga and Ezcurra (2002) and García-Mendoza (2004) reveal that the plants used in plantations are obtained from shoots produced by the rhizome and from bulbils produced by the inflorescence.

Today, it is essential to satisfy the demand for quality plants to establish plantations, increment productivity and reduce production costs. Thus, the use of biotechnological tools, such as in vitro culture of plant cells, tissues or organs, PTC, is a complementary alternative to conventional methods. PTC takes advantage of the totipotency of plant cells to express their capacity to regenerate plants through embryogenesis or organogenesis (Fortes and Pais, 2000;

\footnotetext{
${ }^{*}$ Corresponding author:

Gerardo Rodríguez-Ortiz, División de Estudios de Posgrado e Investigación-Instituto Tecnológico del Valle de Oaxaca (ITVO), Nazareno, Xoxocotlán, Oaxaca, Zip Code 71230, México. E-mail: grodriguez.itvo@yahoo.com

Received: 01 January 2017; Accepted: 07 January 2018
} 
Zeng et al., 2007). This technology permits designing intensive plant production systems with duly controlled propagation environment in which somaclonal variation is minimized (Fortes et al., 2010). The technique consists of aseptic culture of different explants in culture medium and incubation to induce cell division, organogenesis and plant development (Morales et al., 2009; Kehie et al., 2012; Siddique et al., 2015). For this purpose, it is necessary to select plants in the field that are outstanding for their productivity and harvest quality to obtain clonal populations for establishment in plantations (Domínguez-Rosales et al., 2008a; Koné et al., 2013; Sagare and Mohanty, 2015).

Since 1986, research in Oaxaca has been conducted to develop a methodology of in vitro propagation of A. angustifolia. In 1987, the first 12 thousand micropropagated plants were established in a nursery, and in 1988 in the field. Now, we have a methodology that is technically viable but can be improved. Data have been published regarding the stages of propagule multiplication: shoot rooting in preparation for transplanting to soil (Enríquez-del Valle et al., 2005), acclimatization of plants in the greenhouse (Enríquezdel Valle et al., 2009), and development in the nursery (Enríquez-del Valle et al., 2012). However, during stage I of the methodology, establishment of aseptic cultures, at least $50 \%$ of the explants are contaminated by bacteria and fungi. Mroginski and Flaschland (2010) mention the difficulty of quantifying the impact of contamination, but they estimate that, on average, in laboratories dedicated to micropropagation, around $10 \%$ of the cultures are lost. It is of utmost importance to establish aseptically the highest percentage possible of explants that are viable for cell division and morphogenesis to occur.

The physiological condition of the stock plant influences the morphogenetic capacity of its somatic tissues when they are established in vitro (Styer and Chin, 1984). For this reason, it is recommended that in the nursery the stock plant, from which somatic tissues are to be extracted, be subjected to a treatment to improve its nutrient and physiological condition before tissue extraction for in vitro culture. Therefore, to implement Stage I, a high percentage of explants in in vitro culture must be aseptic but also viable to assume cell division and morphogenesis (Niubó et al., 2004). In this regard, there are no data on A. angustifolia Haw. and for this reason the objective of this study was to evaluate the effect of the physiological condition of Agave angustifolia Haw. stock plants on the organogenic response of their somatic tissues when they were established under similar conditions of culture medium. And the hypothesis was that the physiological condition of the stock plant from which the explants were obtained had effect on the stem tissue capacity to assume a process of organogenesis.

\section{MATERIALS AND METHODS}

The study consisted of two stages, each with its respective experiment. Experiment 1 evaluated growth and condition of the stock plants subjected to different nutrient supplies in the nursery. Experiment 2 assessed the organogenic response in vitro of explants obtained from stock plants that exhibited different growth vigor in the nursery.

\section{Experiment 1. Evaluated growth and condition of the stock plants}

Experiment 1 initiated with 40 plants obtained from bulbils from $A$. angustifolia Haw. inflorescences. The plants were 18 months old and had been established in the nursery in individual $4 \mathrm{dm}^{3}$ pots with sandy loam textured soil. Four groups were prepared, each of which received a different irrigation treatment twice a week for seven months. Treatment 1 was irrigation with only water. The other treatments were nutritive solution (NS) at different dilutions of the Steiner formulation (1984): Treatment 2) NS-50\%, Treatment 3) NS-75\%, and Treatment 4) NS$100 \%$. The NS-100\% contains in mg/L: 166.42 N, 30.68 P, 276.44 K, $182.34 \mathrm{Ca}, 49.09 \mathrm{Mg}, 111.15 \mathrm{~S}, 1.25 \mathrm{Fe}, 0.21$ Mn, $0.025 \mathrm{Zn}, 0.076 \mathrm{~B}, 0.005 \mathrm{Cu}$ y $0.021 \mathrm{Mo}$. Also, all of the groups were sprayed with N-trichloromethylthio4-cyclohexene-1,2-dicarboximide fungicide (Bayer ${ }^{\circledR}$ ) and a systemic antibiotic agricultural terramycin, 5\% oxitetracyclin $\left(\right.$ Zoetis $\left.{ }^{\circledR}\right)$, twice a week. After seven months under these conditions, the plants were harvested, and height and number of leaves were quantified and leaf area determined with a Laser Area Meter (CID Bio-Science, Copyright C2016 CID Bio-Sciencie Inc., Camas, WA, USA). Root and leaf volume $\left(\mathrm{cm}^{3}\right)$ were determined by submerging them in a known volume of water in a graduated test tube. Leaf and root fresh weight $(\mathrm{g})$ were determined on a triple bar balance (IROSA® 700 PPW, Mexico) with $0.1 \mathrm{~g}$ precision. The leaves and roots were then placed separately in labeled paper bags and dried in a convection oven (Felisa ${ }^{\circledR}$ Fabricantes Feligneo, S. A. de C.V. Mexico) for two weeks at a temperature of $65^{\circ} \mathrm{C}$. After this time, leaf and root dry weights were determined on a balance. The experiment was established under a completely randomized design. The experimental unit was one plant, and there were 10 replications per treatment. The data were subjected to analysis of variance and comparison of means.

\section{Experiment 2. Organogenesis in stem tissues}

The 40 stock plants that in experiment 1 were separated into groups of 10 subjected to different dosages of fertigation were harvested to evaluate their leaves and root. The stem was taken to the laboratory and superficially disinfected using the following sequence: 1 ) rinsing with running water for $5 \mathrm{~min}$; 2) immersion and 
washing in soapy water for $15 \mathrm{~min}, 3)$ immersion in a $2.5 \mathrm{~g} / \mathrm{L}$ solution of $\mathrm{N}$-trichloromethylthio-4-cyclohexene1,2-dicarboximide fungicide (Bayer $\left.{ }^{\circledR}\right)$ for three min; 4) three rinses with distilled sterilized water; 5) immersion for $2 \mathrm{~min}$ in $90 \%$ ethanol; 6) immersion for $15 \mathrm{~min}$ in a $0.6 \%$ solution of sodium hypochlorite; 7) five rinses with distilled sterilized water. Step four and thereafter of the disinfection process were conducted in aseptic conditions in a horizontal laminar flow bell. The disinfected stems were placed in sterilized glass Petri dishes of $10 \times 100$ $\mathrm{mm}$ and, with sterilized forceps and scalpel, cut into $1.5 \times 1.5 \mathrm{~cm}$ and $0.3 \mathrm{~cm}$ thick fragments. Each fragment was placed in a $145 \mathrm{~cm}^{3}$ culture recipient containing 20 $\mathrm{mL}$ sterilized geled culture medium prepared with MS (Murashige and Skoog, 1962) mineral salts, $1 \mathrm{mg} / \mathrm{L}$ thiamine-HCl, $100 \mathrm{mg} / \mathrm{L}$ de myo-inositol, $30 \mathrm{~g} / \mathrm{L}$ sucrose, $1.5 \mathrm{mg} / \mathrm{L} \mathrm{N}^{6}$ - bencylaminopurine, $1 \mathrm{mg} / \mathrm{L}$ indol-3-acetic acid, $40 \mathrm{~mL} / \mathrm{L}$ coconut milk, $5.6 \mathrm{~g} / \mathrm{L}$ agar, and $250 \mathrm{mg} / \mathrm{L}$ chloramphenicol. After establishing the stem tissues in vitro, the recipients were closed with a polypropylene top and sealed with adherent polyethylene. The cultures were placed in the area of incubation, exposed to white fluorescent lighting $35 \mu \mathrm{mol} / \mathrm{m} 2 / \mathrm{s}$ in $16 \mathrm{~h}$ photoperiods / $8 \mathrm{~h}$ darkness with temperature ranging from 15 to $29^{\circ} \mathrm{C}$. The number of tissue segments (explants) obtained from each stem was counted. During the incubation period, qualitative changes occurring in the tissue fragments in the culture media were observed: cell proliferation (callus), change in pigmentation, and shoot formation. After the eleven weeks, the number of viable uncontaminated stem segments achieved were quantified, as well as the total number of adventitious shoots and the average number of shoots per stem segments (explants) obtained from one stock plant. The experiment was established according to a completely randomized design. The experimental unit was one stem obtained from each stock plant, with 10 replications per treatment. The variables contaminated explants, viable uncontaminated explants, and percentage of contamination were transformed to $\log 10(x)$ to comply with the assumptions of normality and homogeneity of variances. The data were subjected to analysis of variance and comparison of means (Tukey, 0.05). The statistical analysis routines of each experiment were performed using SAS ${ }^{\circledR}$ Statistical software, version 9.0.

\section{RESULTS}

The substrate was sandy loam in texture so this did not supply enough nutriments to the plants. The physiological condition of the stock plants was determined by the magnitude of their growth, observing that the nutrient supply did influence plant growth; fertigated plants grew larger than unfertilized plants. Later, it was observed that the condition and different growth vigor of the stock plant did indeed affect the magnitude of organogenic response of the in vitro cultured stem tissue obtained from these plants.

\section{Experiment 1. Condition of stock plants in response to the level of nutrient supply in the nursery}

Initially, the Agave angustifolia Haw. plants had 14 to 20 leaves and were 25 to $35 \mathrm{~cm}$ tall. After seven months, the plants supplied with different concentrations of nutrients exhibited different sizes in accord with the dosages of fertigation they received. In our study, the analysis of variance showed that the dosage of fertigation had significantly different effects $(\mathrm{P} \leq 0.05)$ on leaf number and length, root and leaf volume, and monthly root and leaf volume increase, and a highly significant effect $(\mathrm{P} \leq 0.01)$ on leaf area (Table 1).

The plants that received $75 \%$ nutrient solution, compared with those that did not receive NS, had increments of 7.8 and 3.8 in total number of leaves and 10.5 and 6.5 $\mathrm{cm}$ in length of largest leaf, 1136.1 and $695.5 \mathrm{~cm}^{3}$ leaf volume, and monthly increases in leaf volume of 162.3 and $99.3 \mathrm{~cm}^{3}$ (Table 2). These values were statistically different (Tukey, 0.05). Most of these characteristics in plants fertigated with $100 \%$ NS did not show additional growth, relative to the plants supplied with $75 \% \mathrm{NS}$; the exception was leaf area $\left(4401.4 \mathrm{~cm}^{2}\right)$, which was 2.73 time larger and significantly different (Tukey, 0.05) than the leaf area of unfertigated plants. It was also observed in all of the groups that the plants began rhizome shoot development with 1.6 to 2.0 shoots per plant, numbers that were not significantly different (Tukey, 0.05) among groups.

\section{Experiment 2. Organogenesis in stem tissue}

Data on time and percentage of contamination reveal that $75.6 \%$ of the explants from unfertigated $A$. angustifolia stock plants became contaminated during the first 9.6 days of incubation. In contrast, $69.5 \%$ of the explants from stock plants that received $75 \%$ NS became contaminated during the first 6.2 days of incubation.

During the organogenesis process of $A$. angustifolia, the explants established in vitro were initially cream colored and smooth. In the first 8 to 15 days of incubation, the explants increased in size by $10 \%$, relative to their initial size, and their surfaces acquired a granular texture. Also, as of day 15 up to day 40 of incubation, the explant showed beginnings of green coloring, initially pale green and changing gradually to lime green. On day 50 small shoots could be observed. The analysis of variance showed that the condition of vigor of $A$. angustifolia stock plants that received different dosages of nutrient solution had a 
Table 1: Summary of the analysis of variance of the characteristics of Agave angustifolia Haw. plants fertigated with different concentrations of nutrients for seven months in the nursery

\begin{tabular}{|c|c|c|c|c|c|c|c|}
\hline \multirow[t]{2}{*}{ SV $^{\mathrm{a}}$} & \multirow[t]{2}{*}{ DF $^{b}$} & \multicolumn{6}{|c|}{ Mean Squares and significance } \\
\hline & & ILc $^{c}$ & LL & DL & NS & RV & VL \\
\hline CSn & 3 & $29.2^{*}$ & $73.3^{*}$ & $0.4^{\mathrm{ns}}$ & $0.3^{\text {ns }}$ & $56444.4^{*}$ & $470643.9^{*}$ \\
\hline Err & 36 & 10.7 & 24.1 & 0.3 & 2.5 & 17049.0 & 132153.3 \\
\hline Total & 39 & & & & & & \\
\hline \multirow[t]{2}{*}{ Sv } & DF & \multicolumn{6}{|c|}{ Mean Squares and significance } \\
\hline & & MIVL & LFW & MILW & RFW & MIRW & LA \\
\hline CSN & 3 & $9605.0^{*}$ & $91309.9^{\text {ns }}$ & $1863.4^{\mathrm{ns}}$ & $31205.8^{\text {ns }}$ & $636.8^{\mathrm{ns}}$ & $5587267.9^{\text {*** }}$ \\
\hline Error & 36 & 2697.0 & 378846.4 & 7731.5 & 11711.7 & 239.0 & 566153.0 \\
\hline Total & 39 & & & & & & \\
\hline
\end{tabular}

aSV: source of variation, CSn: solution concentration. ${ }^{\mathrm{b}} \mathrm{DF}$ : degrees of freedom. ${ }^{\mathrm{IL}}$ : increase in number of leaves, LL: length of largest leaf, DL: diameter of the largest leaf, NS: number of shoots, VR: root volume, MIVR: monthly increases in root volume, VL: leaf volume, MIVL: monthly increases in leaf volume, LFW: leaf fresh weight, MILW: monthly increases in leaf weight, RFW: root fresh weight, MIRFW: monthly increases in root fresh weight, LA: leaf area. ${ }^{d}$ ns: non-significant $(P>0.05)$, *: significant effects $(P \leq 0.05)$, ${ }^{* *}$ : highly significant effects $(P \leq 0.01)(T u k e y$ test, $P<0.05)$

Table 2: Characteristics of Agave angustifolia Haw. plants fertigated with different concentrations of nutrients for seven months in the nursery

\begin{tabular}{|c|c|c|c|c|}
\hline \multirow[b]{2}{*}{ Variable ${ }^{a}$} & \multicolumn{4}{|c|}{ Treatments, dilutions (\%) of Steiner nutrient solution ${ }^{b}$} \\
\hline & Water & 50 & 75 & 100 \\
\hline IL & $3.8 \pm 1.7 \mathrm{~b}$ & $6.6 \pm 4.4 \mathrm{ab}$ & $7.8 \pm 4.3 \mathrm{a}$ & $5.4 \pm 1.0 \mathrm{~b}$ \\
\hline $\mathrm{LL}(\mathrm{cm})$ & $6.5 \pm 4.0 \mathrm{~b}$ & $7.6 \pm 3.8 b$ & $10.5 \pm 6.9 \mathrm{a}$ & $12.5 \pm 4.1 \mathrm{a}$ \\
\hline $\mathrm{DL}(\mathrm{cm})$ & $2.2 \pm 1.3 \mathrm{a}$ & $2.0 \pm 0.6 \mathrm{a}$ & $2.5 \pm 0.3 \mathrm{a}$ & $2.3 \pm 0.6 \mathrm{a}$ \\
\hline NS & $1.7 \pm 53.8 \mathrm{a}$ & $1.6 \pm 1.2 \mathrm{a}$ & $1.6 \pm 1.5 \mathrm{a}$ & $2.0 \pm 2.0 \mathrm{a}$ \\
\hline $\mathrm{RV}\left(\mathrm{cm}^{3}\right)$ & $142.8 \pm 53.8 \mathrm{~b}$ & $285.0 \pm 140.3 a b$ & $\begin{array}{l}269.9 \pm 154.6 \\
a b\end{array}$ & $312.0 \pm 147.2 \mathrm{a}$ \\
\hline $\operatorname{MRV}\left(\mathrm{cm}^{3}\right)$ & $20.4 \pm 7.6 \mathrm{~b}$ & $40.7 \pm 20.0 \mathrm{ab}$ & $38.5 \pm 22.0 \mathrm{ab}$ & $44.5 \pm 21.0 \mathrm{a}$ \\
\hline LV (cm3) & $695.5 \pm 318.1 \mathrm{~b}$ & $714.0 \pm 355.9 \mathrm{ab}$ & $\begin{array}{l}1136.1 \pm 476.9 \\
\mathrm{a}\end{array}$ & $\begin{array}{l}999.0 \pm 270.5 \\
a b\end{array}$ \\
\hline $\operatorname{MLV}\left(\mathrm{cm}^{3}\right)$ & $99.3 \pm 45.4 \mathrm{~b}$ & $102.0 \pm 50.8 \mathrm{ab}$ & $162.3 \pm 68.1 \mathrm{a}$ & $142.7 \pm 8.6 \mathrm{ab}$ \\
\hline LFW (g) & $1145.7 \pm 525.2 \mathrm{a}$ & $1220.0 \pm 754.6 \mathrm{a}$ & $\begin{array}{l}1339.1 \pm 747.2 \\
\mathrm{a}\end{array}$ & $\begin{array}{l}1129.4 \pm 334.0 \\
\mathrm{a}\end{array}$ \\
\hline MILFW (g) & $163.6 \pm 75.0 \mathrm{a}$ & $174.2 \pm 107.8 \mathrm{a}$ & $191.3 \pm 106.7 \mathrm{a}$ & $161.3 \pm 47.7 \mathrm{a}$ \\
\hline RFW (g) & $142.1 \pm 50.0 \mathrm{~b}$ & $175.1 \pm 118.8 \mathrm{ab}$ & $\begin{array}{l}208.8 \pm 113.1 \\
a b\end{array}$ & $272.9 \pm 131.9 \mathrm{a}$ \\
\hline MIRFW (g) & $20.3 \pm 7.1 \mathrm{~b}$ & $25.0 \pm 16.9 a b$ & $29.8 \pm 16.1 \mathrm{ab}$ & $38.9 \pm 18.8 \mathrm{a}$ \\
\hline $\mathrm{LA}\left(\mathrm{cm}^{2}\right)$ & $1610.3 \pm 1008.5 b$ & $2342.3 \pm 218.0 \mathrm{~b}$ & $2735.3 \pm 540.7 \mathrm{~b}$ & $4401.4 \pm 952.5 \mathrm{a}$ \\
\hline
\end{tabular}

alL: increase in number of leaves, LL: length of largest leaf, DL: diameter of largest leaf, NS: number of rhizome shoots, RV: root volume, MRV: monthly increase in root volume, LV: leaf volume, MLV: monthly incrase in leaf volume, LFW=leaf fresh weight, MILFW: monthly increase in leaf fresh weight, RFW: root fresh weight, MIRFW: monthly increase in root fresh weight, LA: leaf area. 'In each column, values with the same letter are not statistically different (Tukey test, $\mathrm{P}<0.05)$, mean \pm standard deviatio.

Table 3: Summary of the analysis of variance of in vitro shoot formation on stem tissue obtained from Agave angustifolia Haw. stock plants that received different nutrient supply in the nursery

\begin{tabular}{|c|c|c|c|c|c|c|c|}
\hline \multirow[t]{2}{*}{$\mathbf{S V}^{\mathrm{a}}$} & \multirow[t]{2}{*}{$\mathbf{D F}^{\mathbf{b}}$} & \multicolumn{6}{|c|}{ Mean Squares ${ }^{c}$ and significance ${ }^{d}$} \\
\hline & & EC & UCVE & TSVE & ASVE & DC & DS \\
\hline $\mathrm{CSn}$ & 3 & $0.03^{n s}$ & $0.20^{\text {ns }}$ & $812.5^{\star *}$ & $32.0^{*}$ & $21.0^{\mathrm{ns}}$ & $2524.8^{* *}$ \\
\hline Error & 36 & 0.06 & 0.19 & 160.8 & 11.0 & 7.8 & 406.5 \\
\hline Total & 39 & & & & & & \\
\hline
\end{tabular}

aSV: source of variation, CSn: concentration of nutrient solution. ${ }^{b} \mathrm{DF}$ : degrees of freedom. ${ }^{\mathrm{C}} \mathrm{EC}$ : contaminated explant, UCVE: uncontaminated viable explant, TSVE: total number of shoots in viable explant from each donor plant, ASVE: Average number of shoots on each viable explant, DC: days to appearance of contamination, DS: days to appearance of shoots. ${ }^{d}$ ns: non-significant $F$ value $(P>0.05)$, ${ }^{*}$ : significant $F$ value $(P \leq 0.05)$, **: highly significant $F$ value $(P \leq 0.01)$ (Tukey test, $P<0.05)$

significant effect $(\mathrm{P} \leq 0.05)$ on stem tissue capacity for organogenesis, formation of adventitious shoots, and a highly significant effect $(\mathrm{P} \leq 0.01)$ on total number of shoots formed on the viable explants obtained from each mother plant and on days to shoot formation (SF) (Table 3).
Stem tissue in the culture medium exhibited different levels of organogenic response, depending on the physiological condition of the stock plants from which they were obtained. Comparing explants obtained from unfertigated stock plants with those from plants fertigated with 100\% nutrient concentration, of the total viable explants, 14.6 and 
Table 4: Percentages of contamination, viable explants, total number of shoots, and average number of shoots on in vitro cultured explants from stem tissue obtained from Agave angustifolia that received different nutrient supply in the nursery

\begin{tabular}{lcclccc}
\hline NS (\%) ${ }^{a}$ & ExpO $^{\mathrm{b}}$ & CExp & DOS & DC & TSE \\
\hline Water & $37.6 \pm 10 \mathrm{a}^{\mathrm{c}}$ & $28.0 \pm 1.3 \mathrm{a}$ & $84.5 \pm 17.7 \mathrm{a}$ & $9.6 \pm 4.0 \mathrm{a}$ & $14.6 \pm 7.3 \mathrm{~b}$ & $3.8 \pm 3.3 \mathrm{~b}$ \\
NS-50\% & $35.5 \pm 11.2 \mathrm{a}$ & $25.1 \pm 15.2 \mathrm{a}$ & $57.5 \pm 23.0 \mathrm{~b}$ & $7.7 \pm 2.9 \mathrm{ab}$ & $20.2 \pm 10.3 \mathrm{ab}$ & $4.8 \pm 3.7 \mathrm{ab}$ \\
$75 \%$ & $29.7 \pm 13.7 \mathrm{a}$ & $11.5 \pm 8.2 \mathrm{a}$ & $47.7 \pm 18.5 \mathrm{~b}$ & $6.2 \pm 1.7 \mathrm{~b}$ & $32.3 \pm 14.0 \mathrm{a}$ \\
$100 \%$ & $30.2 \pm 10.2 \mathrm{a}$ & $25.2 \pm 12.2 \mathrm{a}$ & $56.8 \pm 20.9 \mathrm{~b}$ & $7.0 \pm 1.6 \mathrm{ab}$ & $3.2 \pm 2.4 \mathrm{ab}$ \\
\hline
\end{tabular}

${ }^{a}$ NS: nutrient solution dilution. ${ }^{b}$ ExpO: explants obtained from each plant, ${ }^{\mathrm{C}}$ Exp: contaminated explants, DOS: days to observation of shoots, DC: days to occurrence of contamination, TSE: total shoots on the explants from one plant, SE: shoots on each explant. cln each column, means with the same letter are not significantly different (Tukey test, $\mathrm{P}<0.05$ ), means are \pm the standard deviation

32.7 shoots were formed, visible at 84.6 and 47.7 days of in vitro culture, respectively. In both cases, the differences were significant (Tukey, 0.05) (Table 4).

Nutrient supply to stock plants in the nursery had an effect on their physiological condition, evaluated by several characteristics of size and later, during in vitro culture, by the number of shoots formed on the explants. Table 4 shows that differences between the explants obtained from each of the unfertigated stock plants and those from plants fertigated with 100\% NS were significant (Tukey, 0.05): a total of 14.6 vs 32.7 adventitious shoots and averages of 4.5 and 8 shoots per explant. There was a positive relationship between formation of a larger number of total shoots and average number of shoots per explant and the dosage of fertigation that the stock plant received in the nursery.

\section{DISCUSSION}

Experiment 1. The results show that agave plants supplied with an appropriate quantity of nutrients reached bigger size than the unfertilized plants, coinciding with (Enríquezdel Valle et al. 2000, 2009, 2013). According to Zúñiga (2013), the nutrients form part of the plant's metabolic compounds and increase their capacity for photosynthesis and synthesis of structural compounds, thus increasing rates of formation and growth of their organs.

In our study, after seven months of fertigation, the plants were of different sizes, positively related to the quantity of nutrients they received. This is in agreement with data reported by Enríquez-del Valle et al. (2016), who demonstrated the positive effect of fertigation on growth of $A$. potatorum plants to which Steiner (1984) NS was administrated at different dilutions (1, 20, 40, 60, 80 and $100 \%$ ). Plants fertigated at 1\% NS increased the number of leaves by 9.8 and leaf area, LA, by $125.53 \mathrm{~cm}^{2}$, while those fertigated at $100 \%$ increased the number of leaves by 17 and leaf area by $392.35 \mathrm{~cm}^{2}$. The data obtained on leaf area, in agreement with Warnock et al. (2006), suggest that the magnitude of LA has a positive relationship to nutrient supply and, in turn, LA is related to the capacity to intercept photosynthetically active radiation (PAR) and fixing $\mathrm{CO}_{2}$ to synthesize carbohydrates and accumulate biomass.
Experiment 2. The evidences show the difficulty in obtaining high percentages of aseptic cultures during the first stage of in vitro culture of Agave stem tissue since the tissues are close to the substrate and to populations of microorganisms, originating a high degree of endogenous and exogenous contamination. For this reason, for this type of plant some of the management conditions should be modified in the nursery stage, as described by Deberg and Maene (1985). However, when the stage of establishing aseptic cultures in vitro is over and explants that responded to organogenesis stimulus are obtained, in the next stage of propagule multiplication it is expected that the levels of contamination decrease drastically and the number of shoots on each explant increase notably. During the in vitro establishment of aseptic cultures of node segments of the woody species Legrandia concinna (Phil.), Uribe-Moraga and Cifuentes (2004) reported that of all explants, 81\% died and 19\% were viable. In species such as Musa spp, during in vitro establishment of aseptic cultures, Ortega et al. (2012) obtained 6.6\% contaminated and $93.4 \%$ aseptic cultures when they tested six methods of disinfecting explants. Niubó et al. (2004) described a methodology for decontaminating sugarcane of endophyte and exophyte microorganisms in in vitro culture, combining a surfaceaction biocide with a broad-spectrum systemic biocide. They obtained $90 \%$ of the explants free of exophyte contamination by using mercury chloride $(0.005 \%$ for $10 \mathrm{~min}$ ) and $92 \%$ explants free of endophyte contamination three months after removing gentamicin sulfate $(30 \mathrm{mg} / \mathrm{L}$ for 14 d). Rache and Pacheco (2010) applied fungicides to explant donor Vaccinium meridionale plants to reduce levels of contamination in the stage of aseptic culture establishment in vitro. When the explant donors were not sprayed with fungicides, $80-100 \%$ of the in vitro explants became contaminated, while only $20 \%$ of the explants from sprayed donors became contaminated.

In our study explants obtained from nursery stock plants with the highest nutrient supply formed more shoots in a shorter time than the explants obtained from unfertigated plants or plants supplied with nutriments under the optimum level. No previous studies had shown differences in in vitro organogenic response of explants from Agave plants that varied in physiological condition. It is much 
more frequent to find assessments of variations in the composition of the culture media, mostly of growth regulators. Thus, in $A$. tequilana different number of shoots were formed from explants that were subjected to pulses that consisted of different concentrations $(2.3,4.5,6.8$ and $9.0 \mu \mathrm{M}$ ) of 2,4-D during different periods (one, three, and six days) as a step prior to establishing them in culture media with $0.113 \mu \mathrm{M} 2,4-\mathrm{D}$ plus $4.44 \mu \mathrm{M}$ BA (RamírezMalagón et al., 2008). Aureoles-Rodríguez et al. (2008) assessed shoot formation of two types of explants, tissue from stem and axillary buds of Agave inaquidens, which were established in culture media that varied in type and concentration of cytokinins. They proved that formation of the highest number of shoots occurred from stem tissue established in culture media with $3 \mathrm{mg} / \mathrm{L}$ cytokinin benzyladenine. Domínguez-Rosales et al. (2008b) also varied the type and concentration of cytokinins for in vitro propagation of Agave cupreata, A. difformis, A. karwinskii, $A$. obscura and $A$. potatorum. As explants they used meristematic tissue extracted from plantlets obtained from seeds germinated in vitro. The explants from $A$. cupreata and $A$. karwinskii established in culture medium with 1.5 and $1 \mathrm{mg} / \mathrm{L}$ BA formed 10.5 and 6.1 shoots per explant, respectively. $A$. difformis and $A$. obscura formed 8.5 and 11 shoots per explant in medium with $0.2 \mathrm{mg} / \mathrm{L}$ TDZ, while $A$. potatorum formed 6.9 shoots in medium with 3 $\mathrm{mg} / \mathrm{L}$ kinetin. Valenzuela-Sánchez et al. (2006) described the proliferation of $A$. tequilana shoots via indirect organogenesis, evaluating explants from leaf segments and stem meristem tissue. The greatest proliferation of shoots occurred in three months from meristem segments and calluses established in culture medium with $1.1 \mu \mathrm{M}$ 2,4-D and $44 \mu \mathrm{M}$ 6-benzylaminopurine (BAP).

With Vaccinium meridionale, Rache and Pacheco (2010) obtained up to 4.5 shoots per viable explants from caulinary apexes of adult plants established in culture medium with different concentrations of mineral salts. To propagate four varieties of Vigna subterranea (L.) Verdc., Koné et al. (2013) used explants from cotyledons established in culture media with different types and concentrations of growth regulators, achieving 20 to $30 \%$ viable explants on which an average of six to ten shoots were formed in culture media with $3 \mathrm{mg} / \mathrm{L}$ benzylaminopurine alone or combined with $0.5 \mathrm{mg} / \mathrm{L} \alpha$-naftalenoacetic acid.

Sánchez-Hernández (2009), working with in vitro propagation of squash found differences in the level of organogenic response due to genotype; explants of Cucurbita pepo, variety round zucchini, produced 2 shoots per explant, and Cucurbita maxima, variety Brujita, produced 2.7 shoots after 22 days in similar culture medium. Rosa-Carrillo et al. (2012) evaluated the capacity of regeneration and in vitro propagation of 14 species of Turbinicarpus (Cactaceae).
The efficiencies per species in a single proliferation cycle of 50 to 60 days were from 4.0 shoots per explant in $T$. hoferi and up to 26.3 per explant in T. psendomacrochele subsp. lausseri. Martínez-Palacios et al. (2003) assessed indirect organogenesis in $A$. victoriae reginae, in which regeneration of multiple shoots was induced from axillary buds from stem segments cultured in MS medium with 2,2-4,4 $\mu \mathrm{MBA}$. Arzate-Fernández and Mejía-Franco (2011) used zygotic embryonic axes from mescal agave (Agave angustifolia Haw.) as explants and achieved formation of 40 to 216 somatic embryos in vitro. Summarizing, the results obtained in our study and in those we mentioned conducted with diverse species show that levels of organogenic response depend on several factors: species, genotype within the species, type of explant, physiological condition of the stock plant, composition of the culture medium and physical conditions of incubation, coinciding with Pierik (1987), DomínguezRosales et al. (2008a), Ramírez-Malagón et al. (2008).

The process of organ formation on somatic tissues was described in Nicotiana (Thorpe and Murashige, 1968; Bertrand-Garcia et al., 1992) and Pinus sp. (Villalobos et al., 1984; Thompson and Thorpe, 1997). The process occurs through a sequence of events: parenchima cells are induced to division to form groups of dediferenciated cells, meristemoids formation, meristems and shoots. This process consume a great quantity of energy and occurs active synthesis of nucleic acids, and proteins. At present work the differences in magnitude of organogenesis in Agave angustifolia explants cultured in vitro probably could be affected by the physiological condition of the stock plants from which these were taken.

\section{CONCLUSIONS}

Agave angustifolia plants that were fertigated in the nursery for seven months had better growth than unfertigated plants. Plant vigor was positively related to the quantity of nutrients received in fertigation. When stem tissue explants taken from the more vigorous plants were established in vitro, they produced a larger number of adventitious shoots in a shorter time than explants taken from the less vigorous plants.

\section{ACKNOWLEDGMENTS}

We thank the financial collaboration of the Tecnológico Nacional de México and the Consejo Nacional de Ciencia y Tecnología, for the development of this research.

\section{Authors' Contributions}

S.C.R.R and J.R.E.V: Growth of nursery plants, application of fertilization doses and tissue culture 
technique. G.R.O: Experimental design planning and statistical analysis of data. J.R.L and V.A.V.V: Revision and writing design.

\section{REFERENCES}

Aguirre, D. and L. Eguiarte. 2013. Genetic diversity, conservation and sustainable use of Wilde Agave cupreata and Agave potatorum extracted for mescal production in Mexico. J. Arid. Environ. 90: 36-44.

Arzate-Fernández, A. M. and R. Mejía-Franco. 2011. Capacidad embriogénica de callos inducidos en ejes embrionarios zigóticos de Agave angustifolia Haw. Rev. Fitotec. Mex. 34(2): 101-106.

Aureoles-Rodríguez, F., O. J. L. Rodríguez, J. P. Egaria-Solano, J. Sahagún-Castellanos and O. M. G. Peña. 2008. Propagación in vitro del 'Maguey bruto' (Agave inaequidens Koch), una especie amenazada de interés económico. Rev. Chapingo Ser. Hortic. 4(3): 263-269.

Bertrand-Garcia, R., L. L. Walling and T. Murashige. 1992. Analysis of polypeptides associated with shoot formation in tobacco callus cultures. Am. J. Bot. 79(5): 481-487.

Comisión Nacional para el conocimiento y uso de la biodiversidad (CONABIO). 2006. Capital natural y bienestar social. Redacta, SA. de CV. México, DF.

Domínguez-Rosales, M. S., J. Ma. de la L, G. C. González, V. C. Rosales, L. S. Quiñones D. de, O. S. Delgadillo, J. Mireles and B. E. Pérez. 2008a. El cultivo in vitro como herramienta para el aprovechamiento, mejoramiento y conservación de especies del género Agave. Rev. Invest. Ciencia. 16(41): 53-62.

Domínguez-Rosales, M. S., S. A. G. Alpuche, M. N. L Vasco and M. E. B. Pérez. 2008b. Efecto de citocininas en la propagación in vitro de Agaves Mexicanos. Rev. Fitotec. Mex. 31(4): 317-322.

Enríquez-del Valle, J. R., G. C. Carrillo and J. L. Rodríguez. 2005. Sales inorgánicas y ácido indolbutírico en el enraizado in vitro de brotes de Agave angustifolia. Rev. Fitotec. Mex. 28(2): 175-178.

Enríquez-del Valle, J. R., G. Carrillo, P. Sánchez, N. Rodríguez and C. Mendoza. 2000. Fertilización para la óptima adaptación y vigor de plántulas de tomate (Lycopersicon esculentum Mill.) obtenidos in vitro. Rev. Fitotec. Mex. 23(1): 59-67.

Enríquez-del Valle, J. R., I. Cruz-Valdez and G. Carrillo-Castañeda. 2012. Acclimatization of Agave angustifolia Haw vitro-plants in inert substrates and fertigated with different nutrimental dose. Acta Hortic. 947:101-104.

Enríquez-del Valle, J. R., S. A Estrada, G. Rodríguez-Ortiz, V. A. Velasco-Velasco and G.V. Campos-Angeles. 2013. Sustrato y dosis de fertirriego en la aclimatación de vitro plantas de Agave americana var. oaxacencis. FCA UNCUYO. 45(2): 341-348.

Enríquez-del Valle, J. R., V. A. Velasco-Velasco, G. V. CamposÁngeles, E. Hernández Gallardo and M. N. Rodríguez-Mendoza. 2009. Agave angustifolia plants grown with different fertirrigation doses and organic substrates. Acta Hortic. 843:49-55.

Enríquez-del Valle, J. R., V. S. E. Alcara, G. Rodríguez-Ortiz, M. M. E. Luna and C. M. Vásquez. 2016. Fertirriego en vivero a plantas de Agave potatorum Zucc micropropagadas aclimatizadas. Rev. Mex. Cienc. Agríc. 7(5): 1167-1177.

Fortes, A. M. and M. S. Pais. 2000. Organogenesis from internode-derived nodules of Humulus lupulus var. nugget (Cannabinaceae): histological studies and changes in the starch content. Am. J. Bot. 87(7): 971-979.

Fortes, A. M., F. Santos and M. S. Pais. 2010. Organogenic nodule formation in hop: A tool to study morphogenesis in plants with biotechnological and medicinal applications. J. Biomed. Biotechnol. 2010: 1-16.

García-Mendoza, A. J. 2004. Agaváceas. In: García-Mendoza, A. J., M. J. Ordóñez, M. Briones-Salas (Ed.), Biodiversidad de Oaxaca. Instituto de Biología, UNAM-Fondo Oaxaqueño para la Conservación de la Naturaleza-World Wildlife Fund, México, pp. 159-169.

Kehie, M., S. Kumaria and P. Tandon. 2012. In vitro plantlet regeneration from nodal segments and shoot tips of Capsicum chinense Jacq. cv. Naga King Chili. 3 Biotech. 2: 31-35.

Koné, M., T. Koné, T. H. Kouakou, S. J. Konaté and S. J. S. Ochatt. 2013. Plant regeneration via direct shoot organogenesis from cotyledon explants of Bambara groundnut, Vigna subterranea (L.) Verdc. Biotechnol. Agron. Soc. Environ. 17(4): 584-592.

Martínez-Palacios, A. M. P., V. M. Ortega-Larrocea and R. B. Chávez. 2003. Somatic embryogenesis and organogenesis of $A$. victoriareginae: Considerations for its conservation. Plant Cell Tiss. Org. Cult. 74: 135-142.

Morales, C., C. De la Fe, J. Corbera and J. M. Calaña. 2009. Estudio de la aclimatación de vitro plantas de anturio (Anthurium andreanum Lin.). Rev. Cultivos Tropicales. 30(4): 48-51.

Mroginski, P. S. and E. Flaschland. 2010. Biotecnología y Mejoramiento Vegetal II. Consejo Argentino para la Información y el Desarrollo de la Biotecnología. $2^{\text {nd }}$ ed. Instituto Nacional de Tecnología Agropecuaria (INTA). Buenos Aires., Argentina.

Murashige, T. and F. Skoog. 1962. A revised medium for rapid growth and bioassays with tobacco tissue cultures. Physiol. Plant. 15: 473-479.

Niubó, E., P. Díaz, O. Oliva, R. Portieles, A. Díaz, O. Ancheta, S. Rodríguez, A. Soto A. and C. Sánchez. 2004. Metodología para la obtención in vitro de plantas y tejidos de la caña de azúcar libres de contaminantes exófitos y endófitos. Rev. CENIC Ciencias Biol. 35(3): 154-161.

Nolasco, C. H. 2015. Informe de la producción 2014. Consejo Regulador del Mezcal Denominación de Origen., Oaxaca, México.

Ortega, D. F., A. C. Tamayo, J. Calderón and R. Galván. 2012. Establecimiento aséptico en la micropropagación in vitro de Banano williams (AAA, SUBGRUPO CAVENDISH). Rev. Tierra Trop. 7(2): 205-220.

Pierik, R. L. M. 1987. In Vitro Culture of Higher Plants. Kluwer Academic Publishers., Dordrecht, p. 344.

Rache, C. L. and M. J. C. Pacheco. 2010. Propagación in vitro de plantas adultas de Vaccinium meridionale (Ericaceae). Acta Bot. Bras. 24(4): 1086-1095.

Ramírez-Malagón, R., A. Borodanenko, L. Pérez-Moreno, M. D. Salas-Araiza, H. G. Nuñez-Palenius and N. Ochoa-Alejo. 2008. In vitro propagation of three Agave species used for liquor distillation and three for landscape. Plant Cell. Tiss. Org. Cult. 94(2): 201-207.

Rosa-Carrillo, M. L., M. S. Domínguez-Rosales, M. E. Pérez-Reyes and E. Pérez-Molphe-Balch. 2012. Cultivo y propagación in vitro de cactáceas amenazada del género Turbinicarpus. Rev. Interciencia. 37(2): 114-120.

Sagare, D. B. and I. C. Mohanty. 2015. In vitro regeneration system in rreen gram (Vigna radiata L., Wilczek, cv. Sujata): A recalcitrant legume crop. Res. J. Agric. Sci. 6(1): 64-67.

Sánchez-Hernández, M. A., C. Sánchez-Hernández, C. VillanuevaVerduzco, I. Gil-Vázquez, M., C. Jiménez-Rojas and I. SánchezCabrera. 2009. Multiplicación in vitro vía organogénesis en calabaza. Rev. Agron. Mesoam. 20(1): 11-22.

Secretaria de Agricultura, Ganadería, Desarrollo Rural, Pesca y 
Alimentación (SAGARPA). 2013. Diagnóstico del Sistema Producto Maguey Mezcal del Estado de Oaxaca. Gobierno del Estado de Oaxaca, Fundación Produce Oaxaca A. C., Universidad Autónoma Chapingo., Oaxaca, México.

Siddique, I., N. A. W. Bukhari, K. Perveen and I. Siddiqui. 2015. Influence of plant growth regulators on in vitro shoot multiplication and plantlet formation in Cassia angustifolia Vahl. J. Braz. Arch. Biol. Technol. 58(5): 686-691.

Steiner, A. A. 1984. The Universal Nutrient Solution. In: Proceedings $6^{\text {th }}$ International Congress on Soilless Culture. Wageningen., The Netherlands, p. 633-650.

Styer, D. J. and C. K. Chin. 1984. Meristem and shop tip culture for propagation, pathogen elimination, and germplasm preservation. Hortic. Rev. 5: 221-227.

Thompson, M. R. and T. A. Thorpe. 1997. Analysis of protein patterns during shoot initiation in cultured Pinus radiata cotyledons. J. Plant Physiol. 151: 724- 734.

Thorpe, T. A. and T. Murashige. 1968. Starch accumulation in shootforming tobacco callus cultures. Science. 160: 421-422.

Uribe-Moraga, M. and L. G. Cifuentes. 2004. Aplicación de técnicas de cultivo in vitro en la propagación de Legrandia concinna. Rev.
Bosque. 25(1): 129-135.

Valenzuela-Sánchez, K. K., R. E. Juárez-Hernández, A. CruzHernández, V. Olalde-Portugal, M. E Valverde and O. ParedesLópez. 2006. Plant regeneration of Agave tequilana by indirect organogenesis. In Vitro Cell. Dev. Biol. Plant. 42: 336-340.

Villalobos, V.M., D. W. M. Leung and T. A. Thorpe. 1984. Light- cytokinin interactions in shoot formation in cultured cotyledons explants of radiate pine. Physiol. Plant. 61: 497-504.

Warnock, R., J. Valenzuela, A. Trujillo, P. Madriz and M. Gutiérrez. 2006. Área foliar, componentes del área foliar y rendimiento de seis genotipos de caraota. Agronomía Trop. 56 (1): 21-42.

Zeng, F., X. Zhang, L. Cheng, L. Hu, L. Zhu, J. Cao and X. Guo. 2007. A draft gene regulatory network for cellular totipotency reprogramming during plant somatic embryogenesis. Genomics. 90(2007): 620-628.

Zúñiga, E. L. 2013. Nutrición de Agave Tequilana y Manejo de los Fertilizantes en un Sistema de Producción Intensiva (riego por goteo). Folleto Técnico No. MX-0-310391-33-03-14-0932. Secretaria de Agricultura, Ganadería, Desarrollo Rural, Pesca y Alimentación (SAGARPA) e Instituto Nacional de Investigaciones Forestales, Agrícolas y Pecuarias., México. 